INSIGHTS INTO REGIONAL DEVELOPMENT

ISSN 2669-0195 (online) http://jssidoi.org/IRD/

2020 Volume 2 Number 2 (June)

http://doi.org/10.9770/IRD.2020.2.2(2)

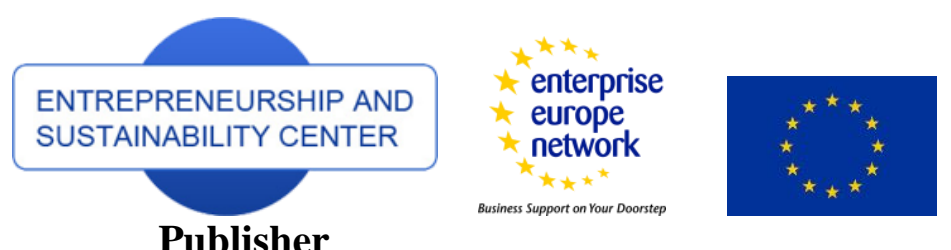

http://jssidoi.org/esc/home

\title{
LIAISONS BETWEEN CULTURE AND INNOVATION: COMPARATIVE ANALYSIS OF SOUTH KOREAN AND LITHUANIAN IT COMPANIES*
}

\author{
Mindaugas Laužikas ${ }^{1}$, Aistė Miliūtė ${ }^{2}$ \\ ${ }^{1}$ Vilnius University Business School, Sauletekio Av. 22, LT-10225 Vilnius, Lithuania \\ ${ }^{1}$ Global Innovation Learning Ecosystem (GILE) Experts, Corradino Industrial Estate, Paola, Malta \\ ${ }^{2}$ Vilnius University Business School, Sauletekio Av. 22, LT-10225 Vilnius, Lithuania \\ ${ }^{2} J S C$ AKVAVITA, Neravu st. 100, Viečiünai, Lithuania \\ E-mails: ${ }^{1}$ mindaugas.lauzikas@gmail.com ; 2aiste_miliute@yahoo.com
}

Received $20^{t}$ February 2020; accepted 21 March 2020, published 30 June 2020

\begin{abstract}
The present publication is centred on the key liaisons of Innovation (Kane et al. 2019, Marwede and Herstatt 2019, Kremer et al. 2019, Narayan, 2019, Lauzikas and Miliute 2017, 2019a, 2019b, and etc.) and Culture (Lauzikas and Mokseckiene 2013, Boon et al. 2019, ASUG, 2019, Clercq and Pereira 2019, and etc.) as two separate components of innovation climate aas well as the main effects of combination of these dimensions on business sustainability (Collett et al. 2019, Halim et al. 2019, Sull et al. 2019, Jin et al. 2019, and etc.). The research problem is how to acknowledge and excel in the areas, related to 'Innovation-Culture Symbiosis', without limiting the progress of innovation or human resource management as separate departments and not stopping a firm from strengthening its competitive advantages, driven by the combination of these dimensions. This is relevant and innovative, because nowadays a great number of efficiency and innovation-driven economies or high-tech industries face the necessity to identify, acknowledge and mitigate weaknesses in human resource or R\&D performance as well as link these dimensions towards innovation culture via modern technologies, innovative managerial processes, strategic collaboration and creative leadership. The purpose of the present paper: comparing the key dimensions of 'Innovation-Culture Symbiosis' in high-tech firms of South Korea and Lithuania (both are education-driven countries) it is expected to illustrate the dynamics of a holistic system of innovation and culture, where these two dimensions are interdependent and form a unique equilibrium (which corresponds to a specific economic and business development stage, position in the value-chain as well as cultural and
\end{abstract}

\footnotetext{
* This research was supported by the project, which has received funding from the European Union's Horizon 2020 research and innovation programme European Research Council (ERC) under the European Union's Horizon 2020 research and innovation programme Marie Sklodowska-Curie Research and Innovation Staff Exchanges ES H2020-MSCA-RISE-2014 CLUSDEVMED (2015-2019) Grant Agreement Number 645730730
}
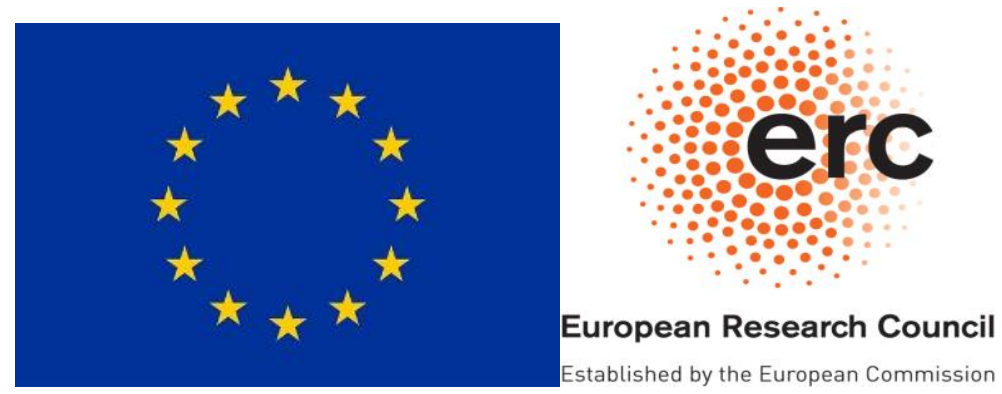


\section{INSIGHTS INTO REGIONAL DEVELOPMENT}

ISSN 2669-0195 (online) http://jssidoi.org/jesi/

2020 Volume 2 Number 2 (June)

http://doi.org/10.9770/IRD.2020.2.2(2)

social norms of a country). Taking into account that sustainable business calls for continuous improvement of products and processes via HRM techniques, R\&D, innovation and technology, the present research results are pertinent and value-adding to high-tech companies of both economies: they could help reach healthier equilibrium between innovation and culture within a specific socio-economic context, and contribute to the establishment of monitoring models which track the dynamics of innovation culture and lead to the bigger economic and social value-added. Taking into consideration the trans-disciplinary holistic nature of innovation culture, which requires a rich knowledge and experience within the present topic, the semi structured interviews with experts of Lithuanian and South Korean IT firms were conducted, the research results of the two economies were compared, and recommendations were provided for both high-tech experts and governmental policy or program developers.

Keywords: culture; innovation; climate; symbiosis; technologies; HRM, high-tech; leadership; strategy; competitive advantages

Reference to this paper should be made as follows: Laužikas, M., Miliūtè, A. 2020. Liaisons between culture and innovation: comparative analysis of South Korean and Lithuanian IT companies. Insights into Regional Development, 2(2), 523537. https://doi.org/10.9770/IRD.2020.2.2(2)

\section{JEL Classification: M130}

\section{Introduction}

The research topic of the present publication is gaining its popularity and momentum: the relation between culture and innovation is being examined via inter-related factors and methodologies. For instance, Kambiz et al. (2018) conducted the survey with 279 companies (providers of automobile parts to Iran Khodro Company) and tackled how innovation was affected by a set of factors, such as organizational culture, knowledge management and organizational learning via combination of knowledge-based approach, competitive advantages framework and identification of main drivers and barriers. Notwithstanding Narayan's (2019) overviewed evolution of the concept of Innovation (from renewing contracts during the 13th century to Schumpeter's intellectual paradigm of innovation or technological and sustainable innovation processes) sustainability, which is a key link between innovation and culture, still leaves a lot of space for interpretation and untapped potential of creating and measuring economic and social value-added. Thus, 'Innovation - Culture' symbiosis might generate synergy effect, if preconditions, such as strategic collaboration or technology, are implemented. Abrahamsen et al. (2016) emphasized business collaboration within networks as an important factor to reach sustainable performance in the context of socio-technical efficiency and effectiveness (Pfote-nhauer and Jasanoff, 2017). Moreover, new technological collaboration possibilities, knowledge sharing and ideas generation or commercialization via modern technologies (such as Blockchain and IT) in a more generic sense could open new horizons and strategic directions as well as contribute to the future where technical and human capital is complimentary (Narayan's, 2019).

Creativity is another important link between innovation and culture. Taking into account the intensity and diversity of creative activities/ projects and growth of the EU Creative Industries, superior than GDP growth, a more thorough look should be taken at what and how innovation models are implemented in these creative sectors as well as how these models could be connected to the present research problem. For instance, having twentythree semi-structured interviews with creative industries' experts of the Netherlands conducted, Koehorst et al. (2019) introduced a model which is partly in line with business intelligence cycle and contains a set of steps from an idea to its commercial value, such as challenge/ context identification, creative ideas generation, draft and/ or complete design, process implementation, and product introduction. Although creative industries are rather specific in terms of business dynamics, the positive experience of creative industries could be of significant valueadded to other creativity-driven sectors, including high-tech industries; particularly, when high-tech content is more frequently used. As it could be expected, these industries possess culture, centred on HR functions and individuals' behaviour, as well as team and organizational cooperation with other stakeholders. On the other hand, creative industries are also driven by efficiency and effectiveness on a more strategic level (Carnevale and Smith, 2013), which requires innovative talent development techniques and enhancement of employees' competences in both more and less creative positions of innovation commercialization cycle. 


\section{INSIGHTS INTO REGIONAL DEVELOPMENT}

ISSN 2669-0195 (online) http://jssidoi.org/jesi/

2020 Volume 2 Number 2 (June)

http://doi.org/10.9770/IRD.2020.2.2(2)

Kremer et al. (2019) also link innovation and culture via creativity which should be facilitated by the HR Department, while observing employees' and teams' behaviour, reshaping attitude and perception towards innovation, paying the attention to listening and knowledge sharing, as well as perfecting managers' and leaders' performance via sustainable and technology-driven learning system. Monitoring and motivating should be executed at different levels (including a rich diversity of managers, leaders and experts, along with 360-degree performance appraisals); hence, engaging stakeholders might contribute to a larger synergy effect and stronger organizational culture (Aguinis, 2019).

Based on Digital Business Report (MIT SMR and Deloitte, 2019) where more than 4,800 managers were interrogated, digitalization and quality of innovation process play an important role in organizations. The survey accentuates the specificity of digitally maturing companies: they are capable to reach success via digital ecosystems and cross-functional teams along with innovative management techniques. Given the innovation intensity in strongly digitalized companies ( $81 \%$ of companies are driven by innovation versus $10 \%$ in young businesses), innovation at a team-level helps raise social trust, self-esteem and motivation, thanks to betterdeveloped innovation culture and its edginess: employees get sufficient time and autonomy for creative activities; they believe in organizational and individual capabilities to adapt to the market trends or implement successful innovation, while less digitalized companies consider innovation as inevitable consequence of market change (when a company has no choice). Organizational openness is a main driver of $80 \%$ of highly digitalized organizations involved in key strategic partnerships with other organizations (versus 33\% of early-stage companies). Innovation at a team-level is driven by cross-functional activities and innovation culture, based on social norms and ethical standards ( $76 \%$ of digital-maturity companies versus $43 \%$ of young business). Notwithstanding its digital maturity, only $35 \%$ of leaders focus on social value-added of digital initiatives and address adequate dissemination practices of such initiatives (MIT SMR and Deloitte, 2019).

The positive experiences of digitally more mature companies or innovation leaders across various industries reveal the significance of innovation culture, based on organizational openness, strategic partnerships, and lifelong learning, particularly in the areas of technologies.

\section{Innovation-Culture Symbiosis}

Waheed et al. (2019) argue that insufficient or fragmented innovation climate limits employees' and organizational creativity; hence, HR management could help engage and empower employees in order to innovate and perform at their best; however, a holistic approach to innovation culture should be developed. Within their survey of employees from the registered IT companies, Qaiser Danish et al. (2019) drew attention towards entrepreneurial culture which embraced attitudes, values, skills, authority and risk at organizational level as well as linked the key dimensions of creativity and readiness for change.

Jin et al. (2019) accentuate sustainability as a key connection between innovation and culture, although efforts of quantifying and measuring this relationship should be analysed through the context of firms' size, development cycle and strategic performance, which in many cases is related to organizational culture. Through the lens of available and allocated inputs for strategic expenditures, the authors come to conclusion that innovation culture incorporates the whole decision-making process along with strategic directions (for instance, sustainability) which affects future outputs via innovation commercialization models. Notwithstanding somewhat bigger financial capacity (available assets) in bigger companies (which creates extensive opportunities to reach innovation-culture synergy effect), both bigger and smaller companies might generate sustainable value-added from $R \& D$ and innovation when strategic directions are related to sustainability and strategic directions derive from organizational culture. Therefore, in parallel with the orientation of strategic directions towards sustainability, a holistic approach to innovation culture should be implemented. For instance, Brem and Utikal (2019) examine how work schedule autonomy affects 233 participants' creativity and efficiency (routine performance) and bring 


\section{INSIGHTS INTO REGIONAL DEVELOPMENT}

ISSN 2669-0195 (online) http://jssidoi.org/jesi/

2020 Volume 2 Number 2 (June)

http://doi.org/10.9770/IRD.2020.2.2(2)

significant implications to organizational managers and leaders: decentralizing work-time planning may affect creativity to the extent of employee's impulsiveness; therefore HR leaders should acknowledge and understand well individual characteristic of each employee in order to optimize their performance.

In light of demographic changes, Marwede and Herstatt (2019) invite corporations to pay more attention to 65+ generation's adults while using the concept of psychological or cognitive distance in the Innovation Department. The representatives of this target group often struggle with using modern technologies; thus, getting socially closer to these customers/ clients requires unique consumer engagement tools, oriented to this demographic group, along with team members and leaders who acknowledge the peculiarities of this target group and make consumer experience smoother and pleasant.

While comparing the cases of leading companies, Sull et al. (2019) identify culture as a driving force of corporate organizations, thanks to its holistic nature (which incorporates a set of values, such as agility, collaboration, customer, diversity, execution, innovation, integrity, performance, and respect). As it could be expected employees' perception regarding the role of innovation in business is more optimistic in technologically more intensive industries, such as Semiconductors, Tech Giants, Communication Equipment or Enterprise Software (standard deviations above or below the mean score across all industries of $2.51,2.21,1,38$ and 1.14 respectively), while Regional Banks, Grocery stores, Airlines or Insurance industries could be examples of a somewhat more negative sentiment of innovation with $-2.74,-1.37,-1,22$ or -1.16 respectively. The examples of leading companies that commit to values might also change stakeholders' behaviour.

Drawing the parallel with cultural and creative organizations' orientation towards economic and social valueadded, Deloitte's (2019) reveals Global Human Capital Trends survey results (with 10,000 respondents in 119 countries), where a special attention is paid to social enterprises that focus on technology-driven innovation culture, centred on effectiveness and efficiency. For instance, although social players are rapidly improving their cloud-based HR systems, only 5 percent of respondents possess a fully integrated HR cloud platform. Moreover, these platforms should be liaised with cognitive technologies, AI, and robotics, while digitalization of work-life should increase comfort and satisfaction of human resources via apps and hubs or employee mobility and engagement schemes.

Within the National Artificial Intelligence Research and Development Strategic Plan 2019 update, the experts of the USA White House link innovation and culture with the dimension of AI R\&D workforce (which incorporates both R\&D and Human Resource strategies), because, according to the U.S. Bureau of Labor Statistics (2019), human capital in terms of numbers of researchers (for instance, computer and information scientists and engineers) will show improvement of $19 \%$ from 2016 to 2026 (showing three times superior improvement than for other positions), while intelligent technologies in the G20 countries should add $\$ 11.5$ trillion turnover (Accenture, 2018). In order to supply sufficient numbers of AI R\&D graduates, the government should direct their programs and policies towards an innovative education system with its connections to the corporate world, because the future AI or IT graduates will drive further growth across various industries.

The White Paper on Innovative Leaders, written by Collet et al. (2019) addressed the relation between innovation and leadership as an engine of sustainable performance. Their investigation led to the implications that leaders were important intermediaries between innovation and culture: they enhanced creativity systems and knowledge sharing processes as well as demonstrated examples to other colleagues or led them in rapidly transforming internal and external strategic collaboration via modern technologies.

While investigating food and high-tech industries in Norway and Germany (explorative qualitative action research), Gonera and Pabst (2019) went one step further and interpreted the liaison of culture and innovation as impacts of Design Thinking techniques and Research and Innovation Consorcia on competitive advantages of organizations. The researchers identified the value-added of using Design Thinking and Research and Innovation 


\section{INSIGHTS INTO REGIONAL DEVELOPMENT}

ISSN 2669-0195 (online) http://jssidoi.org/jesi/

2020 Volume 2 Number 2 (June)

http://doi.org/10.9770/IRD.2020.2.2(2)

Consorcia (which were related to users' engagement and innovation focus) as well as revealed how Design Thinking helped R\&D and Innovation Centres scientifically codify business expectations and/ or practically apply research results in order to strengthen innovation-related competitive advantages of various organizations. This clearly illustrated how organizational culture (including thinking, creating, knowledge sharing, and conducting research) is important, when stakeholders come from completely different backgrounds and environments, marked by diverse variety of status, strategic targets and multifaceted communication styles.

The liaisons of innovation and culture are interpreted at both micro and macro levels. For instance, Mickov and Doyle (2019) link Culture and Innovation with the Economy, while testing this symbiosis via cultural entrepreneurship cases and practices. Such approach indicates that the liaison of innovation and culture generates value-added to both business and economy, as cultural economy can be interpreted as a business, while creative businesses generate a solid value-added to GDP.

Relying on Uwe Palm's (2019) presentation in ASUG Annual Conference, only an organization with innovationdriven culture can succeed in digital transformation, led by collaboration, HR innovation, design-thinking, data management, and intuitive leaders. Moreover, technological improvements should derive from culture, mindset, and strategy, while outcomes should be foreseen, forecasted and tracked in both the shorter and longer run.

Creativity enhancement should be a starting point while linking innovation and culture at different hierarchy levels, while positive experiences of this connection can be witnessed across various regions and countries. For example, the initiative of National Innovation Foundation India to lead the Festival of Innovation and Entrepreneurship (2019) is a good example of recognizing and rewarding citizens' creativity and drawing attention to combination of Science, Technology and Innovation, which in parallel encourages entrepreneurship and engage society. Thus, we can speak about innovative society and bring innovation culture at national level or different sectors and industries of a country, such as Healthcare, Agriculture or Environmental Protection.

Kim et al. (2019) agree that technological improvement expenditure is crucial to strengthen technological competitiveness: modern technology might negatively affect profit margins in the shorter run and might improve profitability in the longer run. While interrogating 183 Malaysian SMEs, Halim et al. (2019) interpret innovationculture symbiosis from the perspective of effects of organizational culture, learning and marketing on innovation success, where data collection, behavioural and cognitive patterns emerge as the key dimensions of innovation process. The authors conclude that innovation climate/ culture is critical for entrepreneurs, while managers should take into account that innovation might cause opposition, thus this phenomenon requires continuous enhancement and motivation along with strategic and innovative HRM techniques.

\section{Perception of innovation culture across various industries and economies}

The interpretation of Innovation-Culture symbiosis differs across various industries and economies. Schoff and Ito (2019) overviewed American and Japanese scholars' insights regarding changing global competitive trends (related to emerging China), presented during the Japan Forum on International Relations (JFIR) and the Carnegie Endowment for International Peace. It is worthy to have a thorough look at competition with China in terms of high-tech innovation. On the one hand, Manufacturing process improvement, Apps, Digital Hubs and R\&D advancement help this technological giant to target over 1 billion local consumers and 800 million internet users, which might lead to introduction of new technological standards and trends (including high-tech control, ethical standards, competition policy) as well as military edge. On the other hand, China's transformation in terms of collaboration projects with strategic partners from other countries and shifting attitude towards innovation as a public property with less control and more digital, shared value economy could lead the world to new social innovation paradigm.

Atkinson and Foote (2019) identify similar trends in China's attempts to catch up other innovation-driven economies: China's innovation strategies (China 2025), accompanied by its R\&D efforts and solid HR supply, are oriented to high-tech development and application of high-tech content in other industries, which indicates that 


\section{INSIGHTS INTO REGIONAL DEVELOPMENT}

ISSN 2669-0195 (online) http://jssidoi.org/jesi/

2020 Volume 2 Number 2 (June)

http://doi.org/10.9770/IRD.2020.2.2(2)

this economy is bit by bit accelerating its innovation processes. Therefore, other peers, such as the US, should address their national policies to improve its competitive technological advancement compared to other regions. Yardeni et al. (2019), recommend thinking outside the box, and based on the US's experience, pay more attention to R\&D and high-tech performance.

Apart from focusing on innovation trends among giant economy leaders, such as China, South Korea, the USA, it is worth overviewing Innovation in smaller economies, such as Israel. Innovation in Israel overview, prepared by Israel Innovation Authority (2019), outlined that this entrepreneurial opportunity-driven country focus on leveraging untapped potential of high-low tech combination via improving high-tech ecosystem in Jerusalem and Beersheba (encouraging research universities and hospitals, technological entrepreneurship, and corporate R\&D centres) as well as intensifying research and innovation in technologically less intensive agriculture sector or industrial development (for instance, hubs for knowledge sharing and collaboration) along with governmental programs and initiatives for technological and knowledge upgrading of various industries.

An interesting insight could be found in the European Innovation Scoreboard Methodology Report (European Commission, 2019), where in spite of cultural differences, a set of indicators, such as human resources, attractive research system and innovation-driven environment should be taken into consideration while linking culture with innovation, while a successful innovation-culture symbiosis could contribute with employment and sales impacts (one is related to social, cultural and intellectual aspect, and another refers to economic and social value-added). Although, based on EUROSTAT (2019), in 2017, the R\&D expenditure of GDP was superior than 3\% in Sweden, Austria, Denmark and Germany, the overall EU's performance in terms of R\&D efforts stood at 2.07\% in 2017, compared to $4.22 \%$ in South Korea ( in 2015) or 3.28\% in Japan (in 2015). Such results might indicate a weak link between innovation and culture and should be incorporated into key-priority innovation policies, programs and strategies.

Based on Deloitte Technology Fast 50 Report for Central Europe (2019), it is important to identify and reward the fastest growing High-Tech companies (based on 4-year revenue growth, 2015-2018) in the region of Central Europe, which is rapidly shifting to Innovation-edge stage and improving its high-low tech combination. The initiative is based on digital hub through which companies from a rich diversity of sectors (such as Communications, Environmental Technology, Fintech, Hardware, Healthcare and Life sciences, Media and Entertainment, Software, and etc.) self-nominate, provide and check financial data and choose their winner. Recognition of peers is a worthy pursuit for innovation performance, while feeling better the local and global environment (as it is part of Deloitte's global Fast 500 program) and initiating important collaboration projects.

Based on European Commission's Independent Expert Report '100 Radical Innovation Breakthroughs for the future', although it is getting difficult to generate a creative idea for radical innovation (for instance, in the area of holistic health) it is even more challenging to run the whole commercialization process of breakthrough innovation: such innovation could contribute to better life quality of people and create bigger social value-added. Not surprisingly, among 100 presented radical innovation examples, 87\% were related to emerging technologies, while only $13 \%$ corresponded to new social practices. This statistical evidence reveals that there is a huge untapped potential for organizational leaders to combine Culture and Innovation in order to generate social valueadded and start the sustainability agenda for future generations.

\section{Methodology}

The in-depth qualitative semi structured interviews with 6 Lithuanian and 6 South Korean IT companies drew attention to the importance of culture in high-tech industries, in particular when modern technologies (such as Artificial Intelligence, IT, Nano technologies, Mechatronics/ Robotics or Biotechnologies) help more traditional companies to raise business efficiency. The culture could be centred around different departments, such as R\&D, Production, Marketing/ Sales, Communication, HR or Business Intelligence, and etc. 
To justify the choice of countries for the comparative analysis, first of all, a set of questions were asked to identify the main drivers of entrepreneurship dynamics of the selected economies. The diagram revealing the role of various factors (in terms of entrepreneurship enhancement organizations) on Culture-Innovation Symbiosis supports the selection of South Korea and Lithuania as research objects of comparative analysis: both countries drive the innovation culture via education and cultural and social norms. Although Governmental Programs and Finance organizations show more support for high-tech business in South Korea, Lithuanian experts stressed the need to reshape the Lithuania's R\&D transfer system and unleash its potential in facilitating knowledge sharing, creativity enhancement and social trust building.

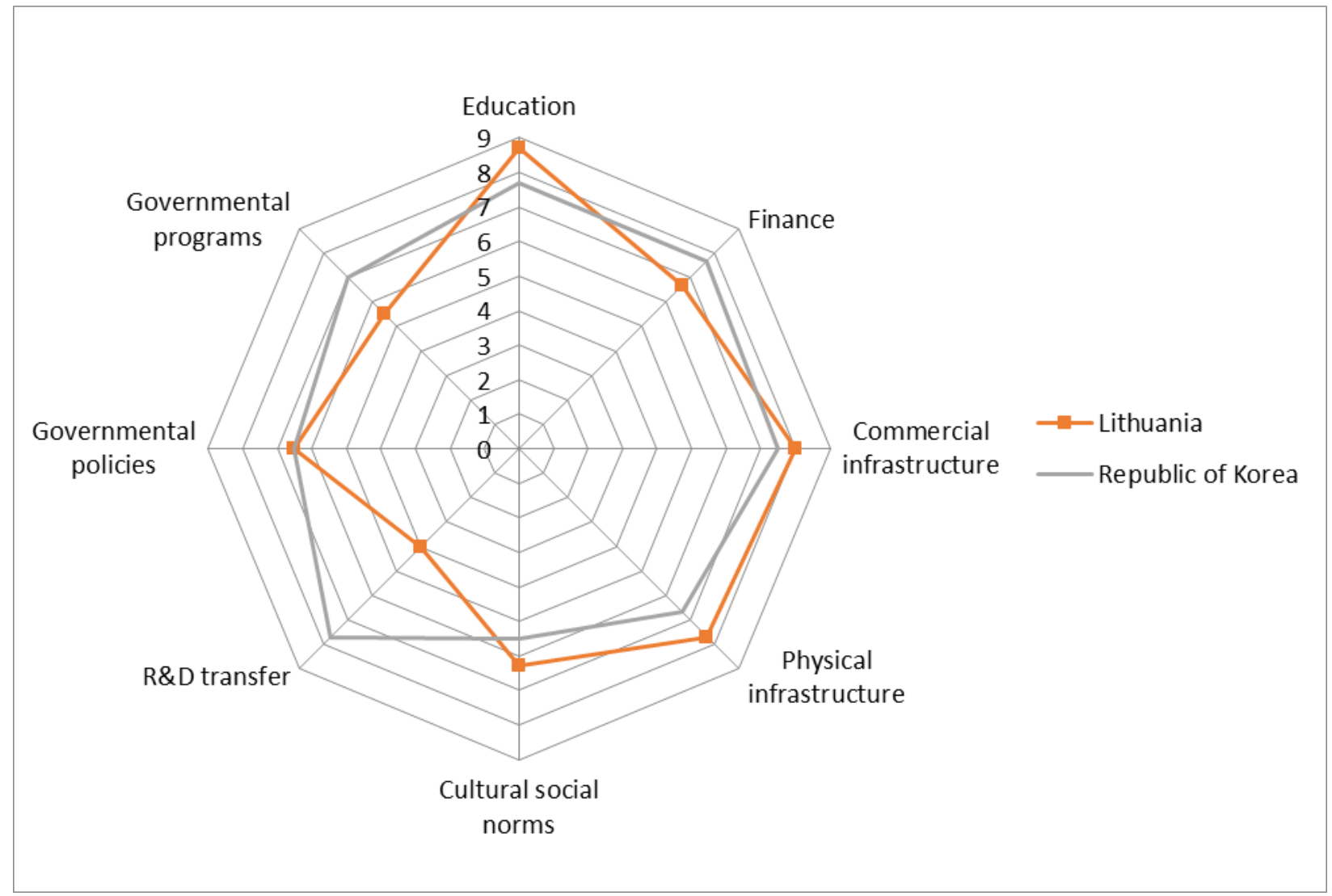

Image 1. The role of entrepreneurship enhancement organizations on innovation culture of high-tech companies. Source: Prepared by paper authors, based on experts' responses

Having two economies (Lithuania and South Korea) chosen for comparison, based on its main innovation drivers (education and knowledge), further on, the top managers with over 7-year experience in IT business were selected and the questionnaire developed in order to identify the main dimensions of 'Innovation-Culture Symbiosis'. Moreover, the coded responses led to comparative results and recommendations for both high-tech companies and experts of Governmental Programs and Policies in South Korea and Lithuania.

\section{Research on Innovation Culture Dimensions in Lithuanian and Korean IT Companies}

Specifying the main success factors/ KPI-s or value-added indicators, all the interrogated experts from South Korea agreed that technologies might free-up time, help cut cost, affect profitability, brand/ image, market share, growth, efficiency, and many other indicators; however, all these factors should be adapted to a specific context of an economy, industry and, in particular, a company. Thus, innovation climate and organizational culture are 
INSIGHTS INTO REGIONAL DEVELOPMENT

ISSN 2669-0195 (online) http://jssidoi.org/jesi/

2020 Volume 2 Number 2 (June)

http://doi.org/10.9770/IRD.2020.2.2(2)

mentioned as the most important preconditions for technological development, innovation commercialization and organizational competitive advantages in general.

Identifying the most relevant technologies, the IT top managers from south Korea and Lithuania focused more on specificity of their clients' industries or economies overall. For instance, South Korean experts mentioned production-related innovative products or processes, such as electric vehicles, renewable energy technologies for buildings and houses, physical cyber systems to emulate real machines and equipment or Matlab ${ }^{\circledR}$ (multi-purpose engineering commercial program); only on expert emphasized the increasing role of AI and big data application. The interrogated Korean experts acknowledged modern technologies' significance in improving efficiency of team leadership, talent development and creativity enhancement functions, which illustrated that their companies already had a well-established innovation climate; moreover, modern technologies were considered as a compulsory factor to strengthen competitive advantages. For instance, one expert from South Korea stated that using Matlab facilitates application of AI in the development of more competitive products is important, while without seamless application capability of using AI and big data companies would face the decline or would terminate operations in the nearest future.

Moreover, a well-established innovation culture and innovative human resource management techniques help free-up time and resources for new technological innovations, in line with employees who are more confident to initiate new projects, share knowledge with other stakeholders. Thus, innovative culture leads to innovation, while innovation help improve innovative culture via digital solutions. Driven by Lithuania's Innovation strategy directions, the interviewed Lithuanian high-tech experts emphasized the role of IT, Lasers and Biotechnologies, while focusing on institutional sales of services and goods, deriving from $R \& D$, open-source innovation/ digital hubs as well as mobile application services. All the Lithuanian experts accentuated the role of modern technologies in knowledge sharing, lifelong learning, and strategic collaboration; nevertheless, many aspects of cultural and social norms (such as social trust, creative leadership or creativity enhancement) according to the respondents, were not in favour of innovation and held innovation processes back. Thus, a special attention should be paid to innovation climate, culture in order to use the potential of divergent thinking or mitigate unpleasant effects of fear of failure, and lack of confidence in entrepreneurship/ intrapreneurship capabilities.

According to the Lithuanian experts, employees and other stakeholders are often not integrated into decisionmaking process; hence, innovation comes first and culture should adapt to it. Such strategy is very dangerous in an economy, characterised by its high-education levels and limited natural resources: in order to compete among other innovation-driven economies, culture should help unleash employees' potential, encourage them to embrace new innovations, raise self-esteem and belief in their knowledge and skills. Therefore, the South Korea's experience in supplying an adequate number of high-tech experts for foreign investors from the perspective of governmental programs and education innovation along with Korean companies' experience in developing effective/ efficient innovation climate with a corresponding creativity system would be of significant value to Lithuanian governmental authorities, universities and firms.

In order to improve innovation processes, first of all, the creativity system should be implemented and innovation processes established. When culture does not come first, it is very difficult to reach sustainable competitive advantages via technologies: stakeholders do not understand what strategic direction they follow, what valueadded they could create and why they apply a particular technology in one or another context.

To continue, technological advantages could be related to the main specialization areas of interrogated companies; for instance, the interrogated Korean experts emphasized that their organizations competitiveness is a technology which uses AI to improve the process control and data utilization capabilities of existing industries, along with big data analysis capability, customer-oriented AI programming, and high reliability technology of AI utilization performance. Such description of the analysed companies leads to understanding how culture is linked to innovation through big data management; in parallel, employees should be technology-intuitive, feel the 


\section{INSIGHTS INTO REGIONAL DEVELOPMENT}

ISSN 2669-0195 (online) http://jssidoi.org/jesi/

2020 Volume 2 Number 2 (June)

http://doi.org/10.9770/IRD.2020.2.2(2)

consumer context well and be capable to customize the analysis, based on client companies' development peculiarities. To provide the service of such high standards, a company must definitely have strong creative leaders, educators and HR managers, that are constitutive part of the organizational culture. As it could be expected, the Lithuanian respondents emphasized the role of information technology and mechatronics while creating the innovation culture, collecting ideas, and later on implementing innovation. According to them, innovation processes are faster than culture enhancement mechanisms, which might be explained by the fact that not all innovations derive from a natural creativity system of an organization; very often, innovation processes might be fragmented, one-off or lacking strategic effectiveness. Given all these challenges, Human Resource Management technologies could be of significant value-added, while strategic collaboration via digital hubs could help share knowledge with more advanced organizations, gather community, engage society, and create the desired synergy effect among stakeholders.

Notwithstanding the specialization and a country of origin of high-tech experts, all of them admitted that technological advancement should derive from creativity which is an important part of innovation culture; thus, innovation could not be created without interesting ideas deriving from divergent thinking, fusion of concepts and diverse schemas of thinking. Moreover, culture could help orient technologies towards switching from a niche to mainstream market. One Korean expert admitted that after securing the quality and performance stability of AI applications in its niche market, the same technology can be applied in the mainstream market: "today's technological competitiveness is a creative technology that can be monopolized, which does not require large investment capital”.

A similar insight was provided by Lithuanian experts - culture could help adapt to rapidly changing market trends and link stakeholders via user-friendly technology, just because this technology is created through strategic collaboration activities.

The sustainability of technological symbiosis with culture might be a challenge to many companies. For instance, one Korean expert accentuated the significance of adapting technologies to the context of a company (development stage, competitive position in the market, value-chain, management style, and specificity of strategic goals). According to this expert, to leverage the value-added of technologies in order to survive and lead in the market, AI application algorithms should serve many enterprises; the technology should be continuously improved to be unique enough. The other five experts emphasized intellectual property rights: a unique patent strategy should be established to maintain exclusivity and prevent similar patents. Hence, culture should support technology application, while technologies should be effectively and efficiently programmed and customised to unleash potential of organizational culture. It is interesting to note that the Lithuanian experts, contrary to the Korean respondents, drew attention to the risk of treating knowledge and innovation as private property, because it might diminish the role of strategic collaboration and jeopardize potential synergy effects. They emphasized the relevance of open-source innovation platforms and digital hubs, where social value-added could be generated together, while patents are more interpreted in the context of radical innovations.

Taking into consideration that South Korea is one of the leading economies in terms of adults involved in shared value-economy activities (GEM 2018/2019), shared value phenomenon was also underlined among the key priority areas by the interviewed Korean experts. According to the Korean respondents, the usage of shared value economy techniques while linking culture and innovation must be strengthened, while the Lithuanian respondents did not acknowledge this area as a key dimension linking culture and innovation.

Although the Lithuanian experts accentuated process/ product or service innovations in their organizations, they admitted that technological improvement/ upgrade happens once per 2 years or even less frequently, while the Korean respondents reported a more frequent technological improvement practice (once a year). This could be related to more ingenious expertise and culture of the R\&D department or higher technological intensity of the 
economy and industry. The symbiosis between innovation and culture is centred more on $R \& D$ or data management strategies among the South Korean experts (creative ideas generation process is related to customers' feedback in terms of reviews or complaints about current products or the use of big data and AI).

Communication is another important management function, mentioned by the Korean and Lithuanian high-tech experts, as a linking dimension between innovation and culture, although its role on Innovation-Culture Symbiosis is perceived differently by the Asian and Baltic respondents. It is interesting to note, that in spite of the accentuated monopolistic nature of the services provided by modern technologies (it was admitted by 4 Korean experts) along with technical specificity and the role of customization, the technology should be sufficiently advanced and powerful to support communication among a big network of stakeholders, where big quantities of data flow and video content is available; thus, modern technologies could contribute to strategic collaboration among various stakeholders, in particular in the areas of production and processing of big data. The Lithuanian experts emphasized more comfort, cost and management aspects of modern technologies, which are again indirectly related to the dimension of intellectual capital and competences. Having the R\&D dimension more accentuated among Korean experts, it is not surprising that the synergy effect among stakeholders is more related to productivity of R\&D personnel or headcount in general thanks to the use of AI applications. The Lithuanian high-tech specialists accentuate the development of independent and self-sufficient creativity system thanks to process innovation, initiated via technology-driven collaboration.

As it is illustrated in the image representing the peculiarities of Innovation-Culture Symbiosis in South Korea, the element of culture is well-established in high-tech organizations; therefore, the core focus of companies is related to efficiency and value-added of innovation processes via R\&D.

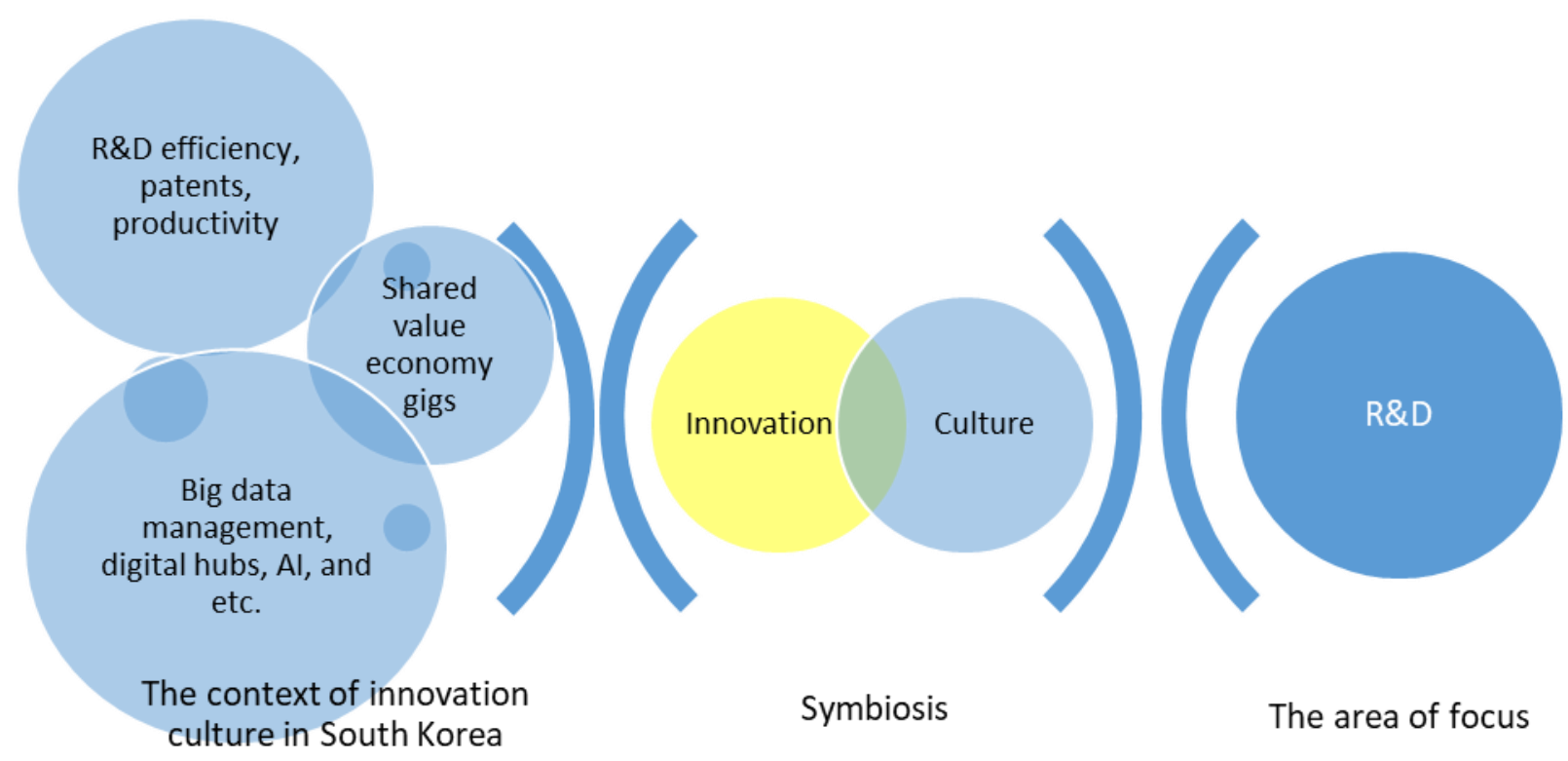

Image 2. Innovation Culture, driven by R\&D

Source: Prepared by paper authors, based on experts' responses 

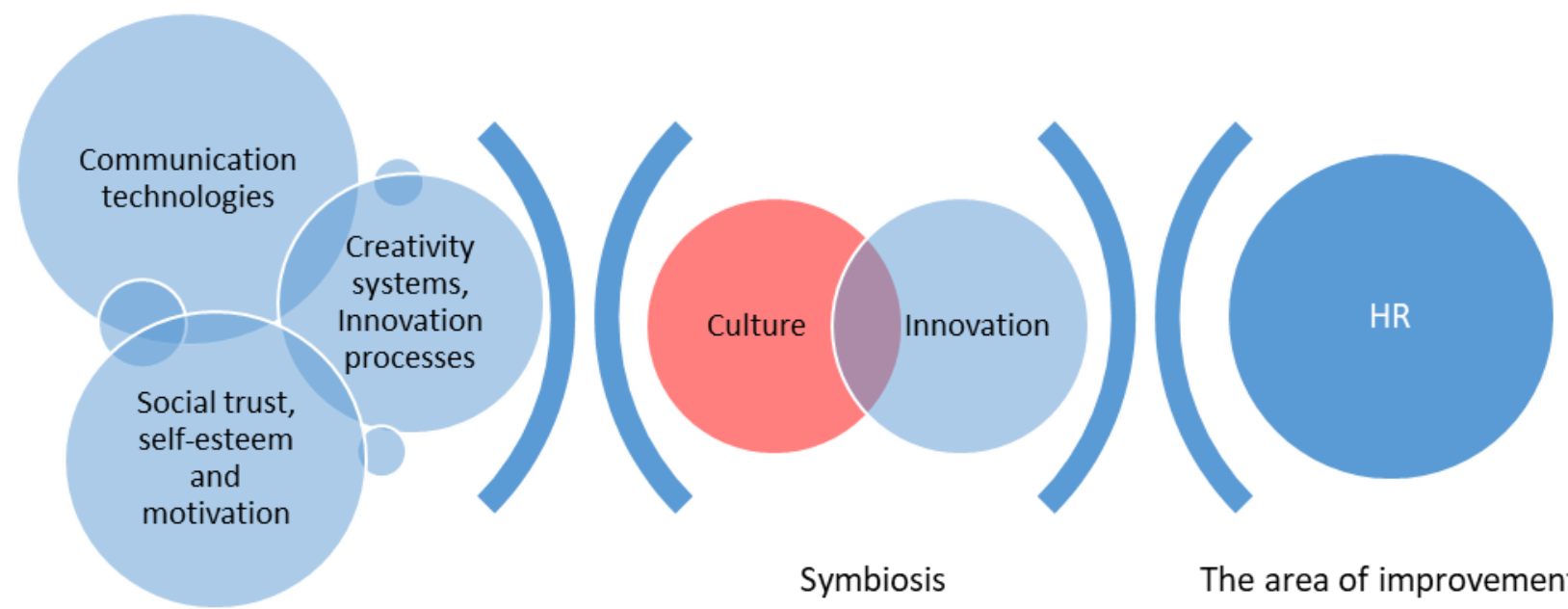

The context of Lithuanian

innovation culture

Image 3. Innovation Culture, driven by HRM

Source: Prepared by paper authors, based on experts' responses

The rapid transformation of Lithuanian economy (former USSR state) from Linear to Innovation-driven status still leaves some areas of improvement in terms of culture and/or cultural and social norms via HR performance. Such trend is logical, because social trust, unpleasant effects of fear of failure or lack of transparency could jeopardize knowledge sharing and innovation commercialization processes. In light of innovation-culture symbiosis, where culture comes first (only then innovation strategy could be effectively addressed by decisionmakers), the future success of Lithuanian high-tech companies might depend on how fast HRM systems are in building healthy innovation climate (based on cultural and social norms) along with sustainable creativity system and lifelong learning process.

\section{Conclusions and Recommendations}

The comparison of innovation culture dimensions in Lithuanian and South Korean IT companies, based on semi structured expert interviews (centred on questionnaire, which derived from scientific literature review), revealed the significance of economic and/ or business development cycles of an economy or a high-tech industry.

Given the assumption that culture should come before strategy and technology, R\&D and technological improvement driven South Korean culture already possess all the necessary elements of innovative HR management (including motivation, creativity enhancement and digitalization) thanks to its technological maturity and deeper innovation traditions; while efficiency-driven culture of Lithuanian high-tech industries is more oriented to building fundamental pillars of HR management and creativity system, which could help strengthen competitive advantages, open up to digital networks as well as excel in terms of innovation commercialization processes. 


\section{INSIGHTS INTO REGIONAL DEVELOPMENT}

ISSN 2669-0195 (online) http://jssidoi.org/jesi/

2020 Volume 2 Number 2 (June)

http://doi.org/10.9770/IRD.2020.2.2(2)

The technological and innovation implementation in Lithuanian companies is more advanced than realignment of culture with innovation processes, which calls for implementation of process managerial technological innovations that could strengthen innovation culture, creativity system and HR Management.

Notwithstanding the similarity between two countries in terms of abundance of human resources and a rich supply of high-tech graduates for technologically-intensive firms, the innovation culture in Lithuanian and South Korean interrogated companies is rather different, due to uniqueness of cultural and social norms and rather different experience of linking culture and innovation.

The present research sheds new light on innovation culture: in order to strengthen fundamentals of innovation culture, decision makers of Lithuanian high-tech companies should analyse the innovation commercialization models of South Korean firms and via HR innovations make innovation process less fragmented, more holistic and knowledge-driven. In the meantime, the Korean high-tech experts should focus on a rapid shift towards employees working hand in hand with robots and other modern technologies as well as the usage of their competitive advantages of R\&D culture in responding to global challenges, such as environmental issues (climate change), healthcare, information security, and social innovation. Along with cutting gap between Lithuanian and South Korean high-tech firms in terms of HR efficiency while supporting creativity and innovation, it is anticipated that these two countries will converge in 'Innovation-Culture Symbiosis', because both of them are driven by human capital as a key resource for high-tech companies. Innovative culture should contribute to innovative processes and bigger value-added, while the role of $R \& D$ culture should become more important.

\section{References:}

Abrahamsen, M.H.; Henneberg, S.C.; Huemer, L.; Naude, P. (2016). Network picturing: Anaction research study of strategizing in business networks. Industrial Marketing Management, 59, 107-119. https://doi.org/10.1016/j.indmarman.2016.02.006

Accenture (2018). It's learning, just not as we know it. How to accelerate skills acquisition in the age of intelligent technologies, p. 40, https://www.accenture.com/t20180920T094705Z w /us-en/ acnmedia/Thought-Leadership-Assets/PDF/Accenture-Education-andTechnology-Skills-Research.pdf)

ASUG, The State of the Community. (2019). Don't Get Eaten by The Big Fish, Bring Innovation Culture into Your Organization, p. 35, https://blog.asug.com/hubfs/2019\%20AC\%20Slide\%20Decks\%20Wednesday/ASUG84077\%20-

\%20Don\%E2\%80\%99t\%20Be\%20Eaten\%20by\%20the\%20Big\%20Fish\%20Bring\%20an\%20Innovation\%20Culture\%20into\%20Your\%2 0Organization.pdf

Atkinson, R.D.; Foote, C. (2019). Is China Catching Up to the United States in Innovation? p. 57, http://www2.itif.org/2019-chinacatching-up-innovation.pdf

Boon, C.; Hartog, D.N.D.; Lepak, D.P. (2019). A Systematic Review of Human Resource Management Systems and Their Measurement. Journal of Management, 45(6), 2498-2537. https://doi.org/10.1177/0149206318818718

Brem, A.; Utikal, V. (2019). How to manage creativity time? Results from a social psychological time model lab experiment on individual creative and routine performance. Creativity and Innovation Management, 28(3), 291-305, https://doi.org/10.1111/caim.12309

Bureau of Labor Statistics, U.S. Department of Labor, Occupational Outlook Handbook (2019). Computer and Information Research Scientists, https://www.bls.gov/ooh/computer-and-information-technology/computer-and-information-research-scientists.htm

Carnevale, A.P.; Smith, N. (2013). Workplace basics: the skills employees need and employers want. Human Resource Development International, 16, 491-501, https://doi.org/10.1080/13678868.2013.821267

Clercq, D.; Pereira, R. (2019). Resilient employees are creative employees, when the workplace forces them to be. Creativity and Innovation Management, 28(3), 329-342, https://doi.org/10.1111/caim.12328

Collett, C.; Graham, J.; Lindsay, J. (2019). Innovative leaders \& leading innovation. A Theoretical and Practical Analysis White Paper. iOpener Institute for People \& Performance, An iOpener Institute Research Paper, May, p. 30, https://iopenerinstitute.com/wpcontent/uploads/2019/05/Innovative-Leaders-and-Leading-Innovation_-May-2019.pdf 


\section{INSIGHTS INTO REGIONAL DEVELOPMENT}

ISSN 2669-0195 (online) http://jssidoi.org/jesi/

2020 Volume 2 Number 2 (June)

http://doi.org/10.9770/IRD.2020.2.2(2)

Danish, R.Q.; Asghar, J.; Ahmad, Z. et al. (2019). Factors affecting "entrepreneurial culture": the mediating role of creativity. Journal of Innovation and Entrepreneurship, 8(14) https://doi.org/10.1186/s13731-019-0108-9

Deloitte (2019). Welcome to the Deloitte Technology Fast 50 Central Europe 2019, p. 59, www.deloitte.com/cefast50

Deloitte by Kaji, J.; Hurley, B.; Gangopadhyay, N.; Bhat, R.; Khan, A. (2019). Leading the social enterprise: Reinvent with a human focus, 2019 Deloitte Global Human Capital Trends, p. 112, https://www2.deloitte.com/content/dam/insights/us/articles/5136_HC-Trends2019/DI_HC-Trends-2019.pdf

Deloitte, prepared by Seeger, S.; Hurley, B.; Bhat, R. (2019). Innovation in Europe. A Deloitte survey on European companies and how digital technologies can strategically enhance innovation, p. 28, https://www2.deloitte.com/content/dam/insights/us/articles/DE 897 Innovation-in-Europe/DI Innovation-In-Europe.pdf

European Commission, prepared by Warnke P. et al. (2019). 100 Radical Innovation Breakthroughs for the future, p. 338, https://ec.europa.eu/info/sites/info/files/research_and_innovation/knowledge_publications_tools_and_data/documents/ec_rtd_radicalinnovation-breakthrough 052019.pdf https://doi.org/10.2777/563770

European Commission, prepared by: Hollanders. H. (2019). European Innovation Scoreboard 2019 - Methodology Report, p. 39, https://www.google.com/url?sa=t\&rct=j\&q=\&esrc=s\&source=web\&cd=2\&ved=2ahUKEwiYjPX-h-

3mAhVHDuwKHRurCFMQFjABegQIBRAC\&url=https\%3A\%2F\%2Fec.europa.eu\%2Fdocsroom $\% 2$ Fdocuments $\% 2 \mathrm{~F} 36282 \% 2 \mathrm{Fattachme}$ nts\%2F1\%2Ftranslations\%2Fen\%2Frenditions\%2Fnative\&usg=AOvVaw3LgztKG V IZ2NFftv8f-v

EUROSTAT (2019). First estimates of Research \& Development expenditure, p. 5, https://ec.europa.eu/eurostat/documents/2995521/9483597/9-10012019-AP-EN.pdf/856ce1d3-b8a8-4fa6-bf00-a8ded6dd1cc1

GEM by Bosma, N.; Kelley, D. (2019). 2018/ 2019 Global Report. p. 152 https://www.gemconsortium.org/report

Gonera, A., Pabst, R. (2019). The Use of Design Thinking in Transdisciplinary Research and Innovation Consortia: Challenges, Enablers and Benefits. Journal of Innovation Management, 7(3), 96-122. https://doi.org/10.24840/2183-0606 007.0030006

Halim, H.A.; Ahmad, N.H.; Ramayah, T. (2019). Sustaining the Innovation Culture in SMEs: The Importance of Organisational Culture, Organisational Learning and Market Orientation. Asian Journal of Business Research 9(2), 20, https://doi.org/10.14707/ajbr.190059

Israel Innovation Authority by Gabay, U.; Linzen, N.; Aharon, A.; Gabay, U.; Kaufman, D. (2019). Innovation in Israel overview, p. 52, Available online: https://innovationisrael.org.il/en/sites/default/files/2018-19_Innovation_Report.pdf

Jin, Z.; Navare, J.; Lynch, R. (2019). The relationship between innovation culture and innovation outcomes: exploring the effects of sustainability orientation and firm size. R\&D Management, 49(4), 607-623. https://doi.org/10.1111/radm.12351

Kane, C.G.; Palmer, D.; Phillips, A.N.; Kiron, D.; Buckley, N. (2019). Accelerating Digital Innovation inside and out; Agile Teams, Ecosystems, and Ethics, MIT Sloan Management Review, June 04, Findings from the 2019 Digital Business Global Executive Study and Research Project In collaboration with Sponsor Logo https://sloanreview.mit.edu/projects/accelerating-digital-innovation-inside-and-out/

Kim, H.; Park, S.Y.; Joh, W.I. (2019). A Study on Technology Development Performance and Technology Commercialization Performance (According to the Technology Development Capability of SMEs Focusing on a Comparative Analysis of Technology Business Groups). Journal of Open Innovation: Technology, Market, and Complexity, 5(3), 65, p. 19, https://doi.org/10.3390/joitmc5030065

Koehorst, M.; van Deursen, A.; van Dijk, J.; De Haan, J. (2019). Exploring the Creative Industries: toward a Classification by Process and Job Functions. Journal of Innovation Management, 7(3), 69-95. https://doi.org/10.24840/2183-0606_007.003_0005

Kremer, H., Villamor, I., Aguinis, H. (2019). Innovation leadership: Best-practice recommendations for promoting employee creativity, voice, and knowledge sharing. Business Horizons, 62(1), 65-74, https://doi.org/10.1016/j.bushor.2018.08.010

Lauzikas, M.; Mokseckienè, R. (2013). The Role of Culture on Entrepreneurship in Lithuania. Social Research, 2(31), 55-69. ISSN 13923110. https://vb.mruni.eu/object/elaba:6092663/ 
INSIGHTS INTO REGIONAL DEVELOPMENT

ISSN 2669-0195 (online) http://jssidoi.org/jesi/

2020 Volume 2 Number 2 (June)

http://doi.org/10.9770/IRD.2020.2.2(2)

Lauzikas M.; Miliute A. (2017). The Role of Education on Entrepreneurship in Lithuania. In: Sauka A., Chepurenko A. (eds)

Entrepreneurship in Transition Economies. Societies and Political Orders in Transition. Springer, Cham; ISBN: 978-3-319-57341-0 (Print)

978-3-319-57342-7. https://doi.org/10.1007/978-3-319-57342-7_9

Lauzikas, M.; Miliute, A. (2019a). Transformational Communication via Evolving Ethical and Moral Norms of Lithuanian Civil Service Organizations, Entrepreneurship and Sustainability Issues, 6(4), 1750-1761, https://doi.org/10.9770/jesi.2019.6.4(14)

Lauzikas, M.; Miliute, A. (2019b). Communication Efficiency and Effectiveness within Strategic Management of Change: insights into Civil Service Organizations, Journal of Security and Sustainability Issues, 8(4), 617-630, https://doi.org/10.9770/jssi.2019.8.4(6)

Marwede, M.; Herstatt, C. (2019). No innovation for the elderly? The influence of cognitive distance in corporate innovation. Creativity and Innovation Management, 28(3), 355-367, https://doi.org/10.1111/caim.12318

Mickov, B.; Doyle, J.E. (2017). Culture Innovation Economy, ISBN 1138219010, p. 210

Narayan, R. (2019). Picturing future imaginaries for innovations towards sustainability transitions. Journal of Innovation Management, 7(3), pp. 7-11, https://doi.org/10.24840/2183-0606 $007.003 \quad 0002$

National Innovation Foundation India (2019). Festival of Innovation and Entrepreneurship, p. 69, http://nif.org.in/upload/fine/A-report-onFestival-of-Innovation-and-\%20Entrepreneur-ship-2019.pdf

Pfotenhauer, S.; Jasanoff, S. (2017). Panacea or diagnosis? Imaginaries of innovation and the'MIT model'in three political cultures. Social studies of science, 47(6), 783-810. https://doi.org/10.1177/0306312717706110

Schoff, J.L.; Ito, A. (2019). Competing with China on Technology and Innovation, Alliance Policy Coordination Brief, Carnegie Endowment for International Peace, October, p. 17, https://carnegieendowment.org/files/ChinaRiskOpportunity-China_Tech.pdf

Select Committee on Artificial Intelligence of the National Science \& Technology Council, the USA (2019). The National Artificial Intelligence Research and Development Strategic Plan: 2019 Update, June 2019, p. 50, https://www.nitrd.gov/pubs/National-AI-RD$\underline{\text { Strategy-2019.pdf }}$

Sull, D.; Sull, C.; Chamberlain, A. (2019). Measuring Culture in Leading Companies, MIT Sloan Management Review and Glassdoor, June 2019, p.17, https://www.glassdoor.com/research/app/uploads/sites/2/2019/06/Measuring-Culture-Final.pdf

Waheed, A.; Miao, X.; Waheed, S.; Ahmad, N.; Majeed, A. (2019). How New HRM Practices, Organizational Innovation, and Innovative Climate Affect the Innovation Performance in the IT Industry: A Moderated-Mediation Analysis, Sustainability 11(621), 21.

https://doi.org/10.3390/su11030621

Yardeni, E.; Johnson, D.; Quintana, M. (2019). US Economic Indicators: R\&D and High-Tech Capital Spending, p. 8, Available online: https://www.yardeni.com/pub/capspendrdtech.pdf

Dr. Mindaugas LAUŽIKAS is a Professor at Vilnius University Business School, Adjunct Professor at American University of Malta, Doctor of Economic Sciences, Director of GILE Experts (Malta). Lecturing experience in countries, such as Georgia, Sweden, France, Spain, Italy, Malta, Moldova, South Korea and Lithuania, is supported by publications in the field of knowledge economy, entrepreneurship and innovation. Research interests: national systems of innovation, entrepreneurship, knowledge and innovation management, innovation and human resource strategies, business intelligence.

ORCID ID: http://orcid.org/0000-0002-6113-7794

Aistė MILIŪTE் is a teacher/researcher at Vilnius University Business School and entrepreneur within the mineral water and healthcare industries, a founder of AKVAVITA company.

ORCID ID: http://orcid.org/0000-0002-9667-3730 
INSIGHTS INTO REGIONAL DEVELOPMENT

ISSN 2669-0195 (online) http://jssidoi.org/jesi/

2020 Volume 2 Number 2 (June)

http://doi.org/10.9770/IRD.2020.2.2(2)

\section{Acknowledgements}

This research was supported by the project, which has received funding from the European Union's Horizon 2020 research and innovation programme European Research Council (ERC) under the European Union's Horizon 2020 research and innovation programme Marie Sklodowska-Curie Research and Innovation Staff Exchanges ES H2020-MSCA-RISE-2014 CLUSDEVMED (2015-2019) Grant Agreement Number 645730730
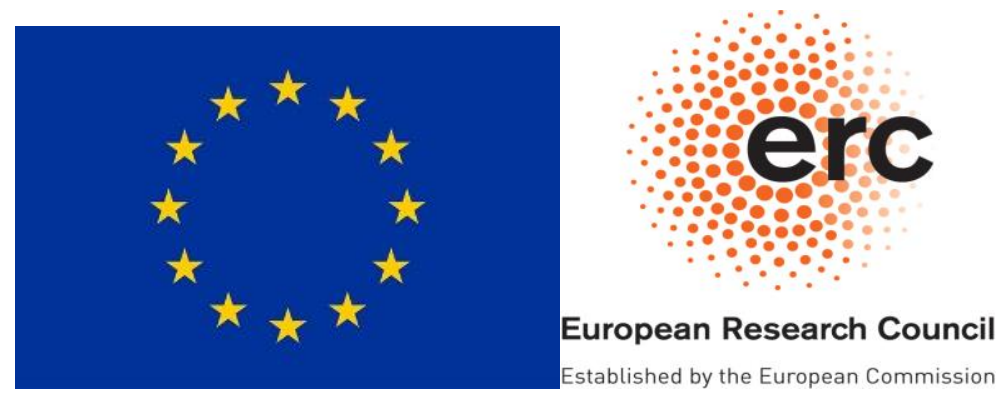

Register for an ORCID ID:

https://orcid.org/register

Copyright (C) 2020 by author(s) and VsI Entrepreneurship and Sustainability Center

This work is licensed under the Creative Commons Attribution International License (CC BY).

http://creativecommons.org/licenses/by/4.0/

cC) (i) Open Access 